\title{
The Chemical Investigations of the Mangrove Plant Avicennia marina and its Endophytes
}

\author{
Feng Zhu* ${ }^{*}$, Xin Chen ${ }^{1}$, Yihua Yuan ${ }^{1}$, Meizhen Huang ${ }^{1}$, Huili Sun ${ }^{2}$ and Wenzhou Xiang ${ }^{2}$ \\ ${ }^{I}$ Department of Chemistry \& Chemical Engineering, Foshan Universtiy, Foshan 528000, P. R. China and ${ }^{2}$ LMB, LAMB \\ and LMM, South China Sea Institute of Oceanology, Chinese Academy of Sciences, Guangzhou 510301, P. R. China
}

\begin{abstract}
A diverse array of bioactive compounds have been isolated and characterized from the mangrove plant Avicennia marina and its endophytes. Extensive chemical investigations of the different parts (barks, leaves, twigs, etc.) of the mangrove plant A. marina and its endophytes (mainly endophytic fungi) resulted in the reporting of the isolation of 123 compounds, and most of them are new or novel compounds. Most of compounds produced by the endophytes were different from the chemical components of the host A. marina, but it can still be found that some metabolites of the endophytes and some chemical components of the host possess the same structure unit. It suggested that there exist some biogenetic relationships between the endophytes and its host. Their biological activities, structural and stereochemical assignments are reported.
\end{abstract}

Keywords: Avicennia marina, mangrove, chemical component, endophyte, metabolite.

\section{INTRODUCTION}

Recently, it was found that the mangrove plants and its endophytes can produce lots of significant natural structures [1]. As a pioneer tree species of mangrove forest ecosystems, Avicennia marina belonging to the family Verbenaceae, is a cosmopolitan species widely distributed along tropical and subtropical coastlines. The barks, leaves, and fruits of this species have been used as traditional medicine in Egypt to treat skin diseases [2]. A. marina contains abundant chemical components. Since Bell et al. [3] reported the bark of A. marina contains triterpenoids (betulic acid $0.3 \%$, taraxerol $0.06 \%$ and taraxerone $0.05 \%$ ), and traces of hydrocarbon, lots of chemical components were isolated from the different parts of A. marina by natural chemists, especially it was found that lots of significant metabolites can be produced by its endophytes recently, which laid foundation for the exploitation of A. marina. Here, the chemical components isolated from the plant and the metabolites produced by its endophytes were reviewed.

\section{CHEMICAL INVESTIGATIONS OF AVICENNIA MA- RINA}

\section{Terpenoids and Steroids}

Many terpenoids and steroids exist in the barks [3], leaves [4-6], flowers [7], fruits [8] of A. marina were identified by HPLC, GC or GC-MS technique. Jia et al. [9] reported the isolation of lupeol (1), betulin (2), $\beta$-sitosterol (3) and ergost-6,22-diene-5,8-epidioxy-3 $\beta$-ol (4), from the leaves of A. marina collected in Beihai, Guangxi province, P. R. China. From the leaves collected in Hainan province, Feng et al. [10] also isolated lupeol and betulin, and another terpenoid, betutinic acid (5).

*Address correspondence to this author at the Department of Chemistry \& Chemical Engineering, Foshan University, Foshan 528000, P. R. China;

E-mail: zhufeng@fosu.edu.cn
Recently, Han et al. [11] reported that the twigs of $A$. marina growing at Xiamen, P. R. China yielded two new abietane diterpenoids, a pair of inseparable epimers $6 \mathrm{H} \alpha$ 11,12,16-trihydroxy-6,7-secoabieta-8,11,13-triene-6,7-dial 11,6-hemiacetal (6) and 6H $\beta$-11,12,16-trihydroxy-6,7secoabieta-8,11,13-triene-6,7-dial 11,6-hemiacetal (7), as well as 6,11,12,16-tetrahydroxy-5,8,11,13-abitetetraen-7-one (8). Compounds 6-8 showed moderate cytotoxic and antimicrobial activities.

\section{Naphthalene Derivatives}

Sutton et al. [12] reported that infection of wound tissue of A. marina seedlings by a fungus belonging to the genus Phytophthora induced the production of three chemicallyrelated naphthofuranone phytoalexins. One was identified as naphtha[1,2-b]furan-4,5-dione (9), and the other two tentatively as 3-hydroxy-naphtha[1,2-b]furan- 4,5-dione (10) and 2-[2'-(2'-hydroxy)propyl]-naphtha[1,2-b]furan-4,5-dione (11). These components present in the extract of the inoculated tissue were found to be inhibitory to the growth of Phytophthrora sp. in vitro bioassay, and accounted for nearly all of the activity of the extract.

From the leaves of A. marina collected in Beihai, Guangxi province, Jia et al. [9] also isolated two naphthoquinone derivatives identified as avicequinone B (12) and avicequinone C (13). In 2007, Han et al. [13] reported seven unusual naphthoquinone derivatives were isolated from the twigs of A. marina collected in Xiamen province, namely, avicennone A-G (14-20), along with the known compounds avicequinone A (21), stenocarproquinone B (22), avicequinone C (13), avicenol A (23), and avicenol C (24). Compounds $13,21,22$ and a mixture of 17 and 18, which contain a 4,9-dione group, showed strong antiproliferative and moderate cytotoxic activities, as well as antibacterial effects. The new ligan, $\left(7^{\prime} S, 8^{\prime} R\right)-4,4^{\prime}, 9^{\prime}$-trihydroxy-3,3',5,5'- tetramethoxy-7,8-dehydro-9-al-2,7'-cycloligan (25), together with the 


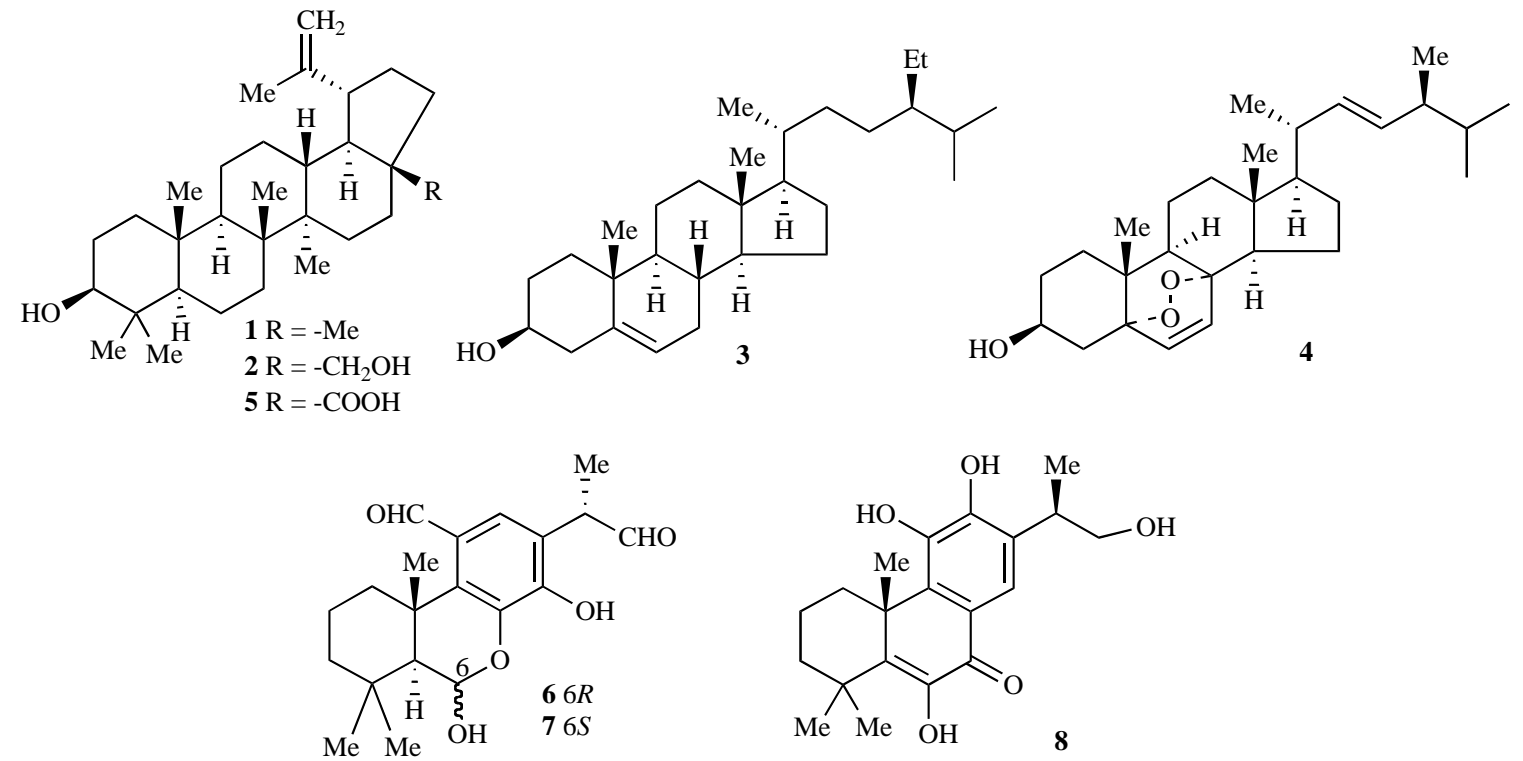

Fig. (1). Terpenoids and steroids from Avicennia marina.<smiles>[R]c1oc2c(c1[R])C(=O)C(=O)c1ccccc1-2</smiles>

$9 \mathrm{R}=\mathrm{H}, \mathrm{R}_{1}=\mathrm{OH}$

$10 \mathrm{R}=\mathrm{H}, \mathrm{R}_{1}=\mathrm{H}$

$11 \mathrm{R}=-\mathrm{C}\left(\mathrm{CH}_{3}\right)_{2} \mathrm{OH}, \mathrm{R}_{1}=\mathrm{H}$<smiles>CC(C)=CC[C@@]12O[C@@H]1[C@@H](O)c1ccccc1C2=O</smiles>

16<smiles>[R]C1c2c(c(OC)c3ccccc3c2OC)OC1C(C)(C)O</smiles><smiles>[R]c1cc2c(o1)C(=O)c1cc([R])c([R])cc1C2=O</smiles>

$12 \mathrm{R}_{1}=\mathrm{R}_{2}=\mathrm{R}=\mathrm{H}$

$13 \mathrm{R}_{1}=\mathrm{R}_{2}=\mathrm{H}, \mathrm{R}=-\mathrm{C}\left(\mathrm{CH}_{3}\right)_{2} \mathrm{OH}$

$17 \mathrm{R}_{1}=\mathrm{OH}, \mathrm{R}_{2}=\mathrm{R}=\mathrm{H}$

$18 \mathrm{R}_{1}=\mathrm{R}=\mathrm{H}, \mathrm{R}_{2}=\mathrm{OH}$<smiles>[R][C@]12C[C@H](C(C)(C)O)O[C@@H]1C(O)c1ccccc1C2=O</smiles>

$19 \mathrm{R}=\mathrm{H}$

$20 \mathrm{R}=\mathrm{OH}$<smiles>COc1cc([C@H]2c3c(cc(OC)c(O)c3OC)C=C(C=O)[C@@H]2CO)cc(OC)c1O</smiles><smiles>[R]C1[C@H]([C@H]2OC(=O)c3ccccc3C2OC)C(=O)C[C@H]1C(C)(C)O</smiles>

$14 \mathrm{R}=\mathrm{H}$

$15 \mathrm{R}=\mathrm{OH}$<smiles>[R]C1C2=C(O[C@H](C(C)(C)O)[C@@H]2[R])C(=O)c2ccccc21</smiles>

$21 \mathrm{R}=\mathrm{OH}$

$22 \mathrm{R}=\mathrm{H}$<smiles>COc1cc([C@H]2c3c(cc(OC)c(O)c3OC)C[C@H](CO)[C@@H]2CO)cc(OC)c1O</smiles>

Fig. (2). Naphthalene derivatives from Avicennia marina.

known compound, lyoniresinol (26), were also isolated by Han et al. [11] from the twigs.

\section{Flavones}

Sharaf et al. [14] isolated a flavone, luteolin 7-Omethylether (27), from A. marina aerial parts collected from Abu-Ramad, $500 \mathrm{~km}$ south of Hurghada (Red Sea shore), and found it showed moderate cytotoxity against BT-20 human carcinoma cells with $\mathrm{ED}_{50}$ of $18 \mu \mathrm{g} / \mathrm{mL}$.

Jia et al. [9] also obtained three flavones from the leaves, and identified them as 5-hydroxy-4', 7-dimethoxyflavone (28), quercetin (29) and kaempferol (30). Four known flavones including 4',5-dihydroxy-3',7-dimethoxyflavone (31), 4',5-dihydroxy-3',5',7-trimethoxyflavone (32), 4',5,7- 
trihydroxyflavone (33), and 3',4',5-trihydroxy-7methoxyflavone (namely 27) were isolated by Feng et al. [15] from the aerial parts of A. marina collected in Hainan island of South China Sea. The scavenging activity of them was evaluated using the $\alpha, \alpha$-diphenyl- $\beta$-picrylhydrazyl (DPPH) radical-scavenging assay. Compounds $\mathbf{3 1}$ and $\mathbf{3 2}$ showed only weak activities, while compounds $\mathbf{3 3}$ and 27 showed moderate activities, with $\mathrm{IC}_{50}$ of 52.0 and 37.0 $\mu \mathrm{g} / \mathrm{mL}$, respectively. Another flavone, 5,7-dihydroxy3',4',5'-trimethoxyflavone (34), was also isolated by them [10] later.<smiles>[R]c1cc(O)c2c(=O)c([R])c(-c3cc([R3])c([R4])c([R3])c3)oc2c1</smiles>

$$
\begin{aligned}
& 27 \mathrm{R}_{1}=\mathrm{R}_{5}=\mathrm{H}, \mathrm{R}_{2}=\mathrm{OMe}, \mathrm{R}_{3}=\mathrm{R}_{4}=\mathrm{OH} \\
& 28 R_{1}=R_{3}=R_{5}=H, R_{2}=R_{4}=O M e \\
& 29 \mathrm{R}_{1}=\mathrm{R}_{2}=\mathrm{R}_{3}=\mathrm{R}_{4}=\mathrm{OH}, \mathrm{R}_{5}=\mathrm{H} \\
& 30 \mathrm{R}_{1}=\mathrm{R}_{2}=\mathrm{R}_{4}=\mathrm{OH}, \mathrm{R}_{3}=\mathrm{R}_{5}=\mathrm{H} \\
& 31 \mathrm{R}_{1}=\mathrm{R}_{5}=\mathrm{H}, \mathrm{R}_{2}=\mathrm{R}_{3}=\mathrm{OMe}, \mathrm{R}_{4}=\mathrm{OH} \\
& 32 \mathrm{R}_{1}=\mathrm{H}, \mathrm{R}_{2}=\mathrm{R}_{3}=\mathrm{R}_{5}=\mathrm{OMe}, \mathrm{R}_{4}=\mathrm{OH} \\
& 33 \mathrm{R}_{1}=\mathrm{R}_{3}=\mathrm{R}_{5}=\mathrm{H}, \mathrm{R}_{2}=\mathrm{R}_{4}=\mathrm{OH} \\
& 34 \mathrm{R}_{1}=\mathrm{H}, \mathrm{R}_{2}=\mathrm{OH}, \mathrm{R}_{3}=\mathrm{R}_{4}=\mathrm{R}_{5}=\mathrm{OMe}
\end{aligned}
$$

Fig. (3). Flavones from Avicennia marina.

\section{Glucosides}

\section{Iridoid Glucosides}

It has been reported that there is no general agreement on the taxonomy of the mangrove plant genus Avicennia. The genus is considered either as a member of the family Verbenaceae or the family Avicenniaceae. The metabolism of iridoids of dicotyledons has been considered as an important taxonomic character.

In 1985, König et al. [16] reported that seven iridoid glucosides were isolated from a methylated extract of the leaves of A. marina obtained from wild growing plants in Ceylon. These iridoids glycosides are geniposidic acid (35), 2'cinnamoyl-mussaenosidic acid (36), geniposide (37), mussaenoside (38), 2'-cinnamoyl-mussaenoside (39), 10-O-(5phenyl-2,4-pentadienoyl)-geniposide (40), 7-O-(5-phenyl2,4-pentadienoyl)-8-epiloganin (41), respectively. Evidence is presented that the iridoids occur as the free acids in the plant. They pointed out that the accumulation of iridoids in this species indicated a fairly close relationship between the genus Avicennia and the family Verbenaceae.

In 2001, Shaker et al. [17] isolated three new iridoid glucosides, 10-O-[(E)-cinnamoyl]-geniposidic acid (42), 10$O$-[(E)-p-coumaroyl]-geniposidic acid (43), $10-O$-[(E)caffeoyl]-geniposidic acid (44) and the known iridoid glucoside, 2'-O-[(E)-cinnamoyl]mussaenosidic acid (36) from $A$. marina. In 2006, Feng et al. [15, 18] obtained two new iridoid glucosides, namely, 2'-O-[(2E,4E)-5-phenylpenta-2,4dienoyl]mussaenosidic acid (45) and 2'-O-(4mehtoxycinnamoyl)mussaenosidic acid (46), together with a known iridoid glucoside, 2'- $O$-coumaroylmussaenosidic acid (47), from the aerial parts of A. marina. Compounds 45 - 47 showed weak radical scavenging activity to DPPH. In 2008,
Sun et al. [19] reported that the isolation and characterization of five new iridoid glucosides, marinoids A - E ( 48 - 52 ), along with the known iridoid glucosides 36, 46 and 47 from the leaves of $A$. marina collected in the coast of Xiamen, Southern China. They pointed out that the iridoid glucosides in the leaves of plant $A$. marina may play a role for chemical defense against ecological invasion.

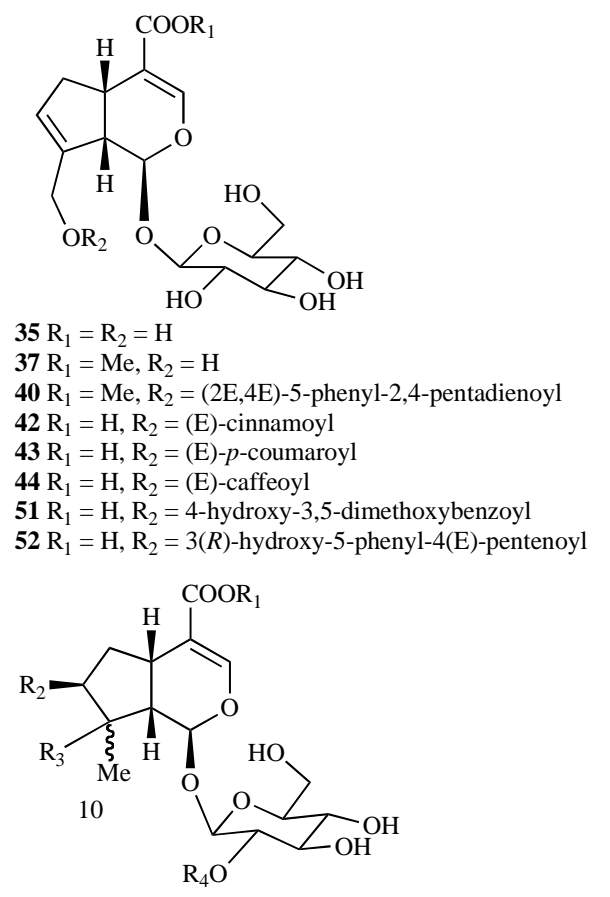

\footnotetext{
$36 \mathrm{R}_{1}=\mathrm{R}_{2}=\mathrm{H}, \mathrm{R}_{3}=\mathrm{OH}, \mathrm{R}_{4}=$ (E)-cinnamoyl, Me-10alpha $38 \mathrm{R}_{1}=\mathrm{Me}, \mathrm{R}_{2}=\mathrm{R}_{4}=\mathrm{H}, \mathrm{R}_{3}=\mathrm{OH}$, Me-10alpha $39 \mathrm{R}_{1}=\mathrm{Me}, \mathrm{R}_{2}=\mathrm{H}, \mathrm{R}_{3}=\mathrm{OH}, \mathrm{R}_{4}=(\mathrm{E})$-cinnamoyl, Me-10alpha

$41 \mathrm{R}_{1}=\mathrm{Me}, \mathrm{R}_{3}=\mathrm{R}_{4}=\mathrm{H}, \mathrm{R}_{2}=$ (2E,4E)-5-phenyl-2,4-pentadienoyl, Me-10alpha $45 \mathrm{R}_{1}=\mathrm{R}_{2}=\mathrm{H}, \mathrm{R}_{3}=\mathrm{OH}, \mathrm{R}_{4}=(2 \mathrm{E}, 4 \mathrm{E})-5$-phenyl-2,4-pentadienoyl, Me-10alpha $46 \mathrm{R}_{1}=\mathrm{R}_{2}=\mathrm{H}, \mathrm{R}_{3}=\mathrm{OH}, \mathrm{R}_{4}=(\mathrm{E})$-4-methoxycinnamoyl, Me-10alpha

$47 \mathrm{R}_{1}=\mathrm{R}_{2}=\mathrm{H}, \mathrm{R}_{3}=\mathrm{OH}, \mathrm{R}_{4}=(\mathrm{E})$ - -coumaroyl, Me-10alpha

$48 \mathrm{R}_{1}=\mathrm{R}_{2}=\mathrm{H}, \mathrm{R}_{3}=\mathrm{OH}, \mathrm{R}_{4}=(\mathrm{E})$-cinnamoyl, Me-10beta

$49 \mathrm{R}_{1}=\mathrm{R}_{2}=\mathrm{H}, \mathrm{R}_{3}=\mathrm{OH}, \mathrm{R}_{4}=(\mathrm{E})-4-$ methoxycinnamoyl, Me-10beta

$50 \mathrm{R}_{1}=\mathrm{R}_{2}=\mathrm{H}, \mathrm{R}_{3}=\mathrm{OH}, \mathrm{R}_{4}=(\mathrm{E})$ - $p$-coumaroyl, Me-10beta
}

Fig. (4). Iridoids glucosides from Avicennia marina.

\section{Phenylpropanoid Glycosides}

Fauvel et al. [2] isolated three phenylpropanoid glycosides from the methanol extracts of $A$. marina leaves. They were identified as verbascoside (53), isoverbascoside (54) and derhamnosylverbascoside (55). Compounds 53 and 54 were also isolated by Feng et al. [10] from the leaves of A. marina collected in Hainan province. In 2008, Han et al. [11] also reported the isolation of diacetaylmartynoiside (56) from the twigs.

\section{Flavonoids}

In 2000, Sharaf et al. [14] found the methanol extract of the aerial parts of $A$. marina yielded four flavonoids, namely, chrysoeriol 7- $O$-glucoside (57), isorhamnetin 3- $O$-rutinoside (58), luteolin 7-O-methylether $3^{\prime}-O-\beta$-D-glucoside (59) and its galactoside analogue (60). Compounds 59 and 60 are new flavonoids. Compound $\mathbf{5 9}$ showed moderate cytotoxic against BT-20 human carcinoma cells with $\mathrm{ED}_{50}$ of $16 \mu \mathrm{g} /$ $\mathrm{mL}$. 


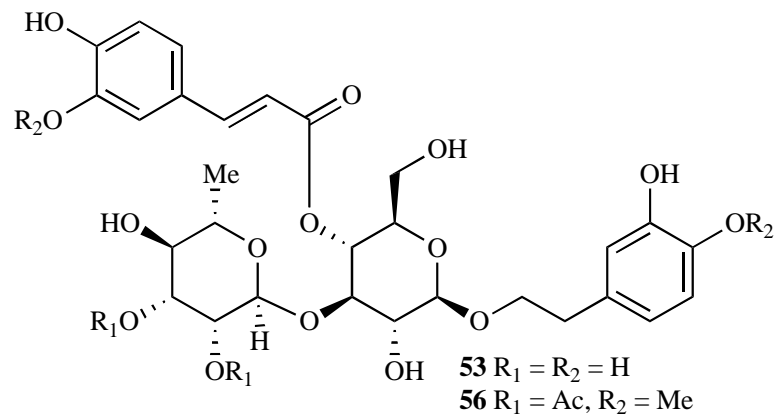<smiles>CC(=O)/C=C/c1ccc(O)c(O)c1</smiles><smiles>CO[C@H]1O[C@H](OCCc2ccc(O)c(O)c2)[C@@H](O)[C@H](OC2O[C@H](C)[C@@H](O)[C@H](O)[C@@H]2O)[C@H]1O</smiles><smiles>O=C(/C=C/c1ccc(O)c(O)c1)O[C@@H]1[C@@H](O)[C@H](O)[C@@H](OCCc2ccc(O)c(O)c2)O[C@@H]1CO</smiles>

Fig. (5). Phenylpropanoid glycosides from Avicennia marina.

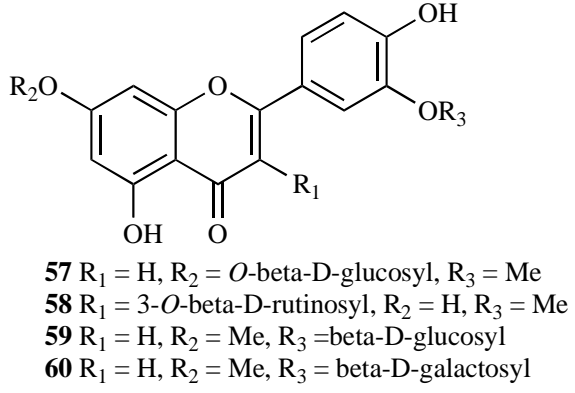

Fig. (6). Flavonoids from Avicennia marina.

\section{Abietane Diterpenoid Glucosides}

A new abietane diterpenoid glucoside, 11-hydroxy8,11,13-abietatriene 12- $O$ - $\beta$-xylopyranoside (61), and a known compound lyoniresinol $9^{\prime}-O-\beta$-D-glucopyranoside (62) were isolated by Han et al. [11] from the twigs of $A$. marina.<smiles>COc1cc([C@H]2c3c(cc(OC)c(O)c3OC)C[C@@H](CO)[C@@H]2CO[C@H]2O[C@H](CO)[C@@H](O)[C@H](O)[C@H]2O)cc(OC)c1O</smiles>

Fig. (7). Abietane diterpenoid glucosides from Avicennia marina.

\section{The Others}

Two biosynthesis precursors for iridoids were also isolated from A. marina, namely, $p$-methoxy cinnamic acid (63) obtained by Jia et al. [9], and 3(R)-hydroxy-5-phenyl-4(E)pentanoic acid (64) obtained by Sun et al. [19]. Syringaresi- nol (65) and indolyl-3-carboxylic acid (66) were isolated by Feng et al. [10]. Compound 66 is the only one alkaloid isolated from A. marina.<smiles>COc1ccc(/C=C/C(=O)O)cc1</smiles>

63<smiles>COc1cc(C2OCC3COC(c4cc(OC)c(O)c(OC)c4)C32)cc(OC)c1O</smiles>

Fig. (8). The other chemical components from Avicennia marina.

\section{CHEMICAL INVESTIGATIONS OF THE ENDO- PHYTES OF AVICENNIA MARINA}

The mangrove habit has proved to be a rich source of new fungal species, and these now form the second largest ecological sub-group of marine fungi. Endophytes are defined as fungi colonizing healthy plant tissue without causing overt symptoms in or apparent injury to the host. Research on the metabolites of endophytes can reveal the relationship between them and their hosts. Zheng et al. [20], Deng et al. [21], Tariq et al. [22] and Chen et al. [23] reported the isolation of fungi from A. marina, and found most of them showed antibacterial or antitumor activities.

\section{Xyloketals, Xyloallenolides and its Precursors}

Xyloketals are most interesting ketals produced by the endophytic fungus Xylaria sp. (No. 2508) from the seeds of 
A. marina in Mai Po, Hong Kong. In the previous study, the fungus was shown to produce xyloketals A-I (67-75) [24-28] and xyloallenolide A (76) [29], two chemical families with novel frameworks, and exhibited strong activity against Lcalcium channels and inhibition of acetylcholine esterase. Subsequently, fermentation of the fungus in large scale yielded three metabolites [30], named xyloketal J (77), xyloester A (78), and xyloallenolide B (79) (which belong to a new series of compounds), and a known substituted dihydrobenzofuran (80). It was found that xyloketal C (69) slowly rearranged to xyloketal $\mathrm{B}(\mathbf{6 8})$ in $\mathrm{DMSO}-d_{6}$ solution at room temperature. Compound $\mathrm{F}$ (72) also can be synthesized by condensation of xyloketal B (68) with formaldehyde. It is biogenetically interesting that compounds 77, 78, and $\mathbf{7 9}$ possess a substituted dihydrobenzofuran unit (80).

In addition, two aromatic allenic ethers (81 and 82) [29] and five phenols (83-88) $[24,31,32]$ were also produced by the fungus. Compounds $\mathbf{8 5}$ and $\mathbf{8 8}$ belong to isocoumarin.

\section{Cyclic Peptides}

The previous compound xyloallenolide A (76) is a novel cyclic peptide containing an allenic ether of a $N-(p-$ hydroxycinnamoyl)amide. Li et al. [33, 34] isolated five cyclic dipeptides, namely cyclo-(Tyr-Leu) (89), cyclo-(PheAla) (90), cyclo-(Ala-Val) (91), cyclo-(Pro-Gly) (92) and 5isobuty1-2,4-imidazolidinedione (93), and one new cyclic pentapeptide, $\quad$ cyclo- $\left(L-P h e-L-L^{2}{ }^{1}-L-L^{2}{ }^{2}-L-L^{2} u^{3}-L-I l e\right)$ (94), from the fungus (No. 2524) isolated from a seed of $A$. marina from Hong Kong. Compound 94 exhibits inhibitory activity against human heptoma cell line Bel-7402. The cellular livability was $67 \%$ at the dose of $15 \mu \mathrm{g} / \mathrm{mL}$. However, no dose-related effects were observed for dosages between 15 and $500 \mu \mathrm{g} / \mathrm{mL}$. Other results showed that these compounds do not exhibit significant cytotoxicity. Generally, most cyclopeptides or cyclic depsipeptides from microorganisms presented D-amino acids or unusual amino acids. They often possess unusual pharmacological properties, including as antibiotics, toxins, immunosuppressants and ion transport regulators. However, the cyclic peptide 94 is composed of only the usual L-amino acids residues with hydrophobic side chains. Its simple architecture may explain the absence of potent cytotoxicity.

Zhu et al. [35, 36] also isolated four cyclic dipeptide, cyclo-(Tyr-Leu) (89), uracil (95) and cyclo-(Phe-Phe) (96)<smiles>C[C@@H]1CO[C@]2(C)Oc3c4c(c5c(c3C[C@@H]12)O[C@@]1(C)OC[C@@H](C)[C@H]1C5)O[C@@]1(C)OC[C@H](C)[C@@H]1C4</smiles><smiles>C[C@@H]1CO[C@]2(C)Oc3cc(O)c4c(c3C[C@H]12)O[C@]1(C)OC[C@H](C)[C@H]1C4</smiles><smiles>C[C@H]1CO[C@]2(C)Oc3cc4c(c(O)c3C[C@@H]12)C[C@@H]1[C@@H](C)CO[C@]1(C)O4</smiles><smiles>CC(=O)c1ccc2c(c1O)C[C@H]1[C@@H](C)CO[C@]1(C)O2</smiles>

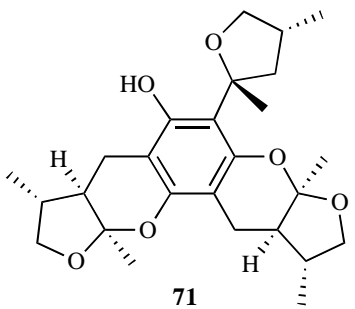

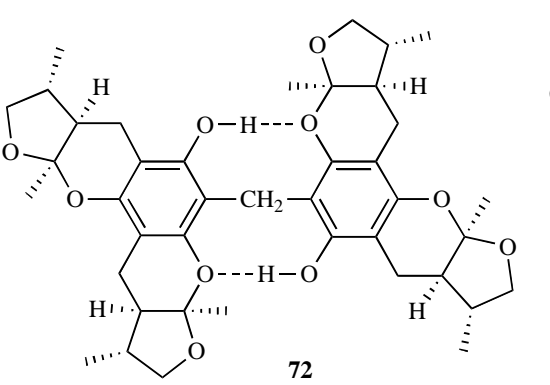<smiles>CC(=O)c1cc2c(cc1O)O[C@]1(C)OC[C@H](C)[C@H]1C2</smiles>

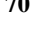<smiles>C[C@H]1CO[C@]2(C)OC3=C(CC12)C(=O)C1=C(C3)O[C@@]2(C)OC[C@H](C)[C@H]2C1</smiles>
75<smiles>C=C=CCOc1ccc(/C=C/C(=O)N[C@@H](CCCCN(C)C(=O)[C@@H](C)N(C)C(=O)[C@@H](C(C)C)N(C)C)C(=O)NC)cc1</smiles><smiles>C=C(C)C1Cc2cc(Cc3c(O)c4c(c5c3O[C@@]3(C)OC[C@H](C)[C@H]3C5)O[C@@]3(C)OC[C@H](C)[C@H]3C4)ccc2O1</smiles><smiles>C=C=CCOc1ccc(COCc2ccc(O)c(C)c2)cc1</smiles><smiles>C=C=CCOc1ccc(/C=C/C(=O)OC)cc1</smiles>

80<smiles>COc1cc(O)ccc1C(C)=O</smiles><smiles>C[C@H]1Cc2ccc(O)c(O)c2C(=O)O1</smiles>

Fig. (9). Xyloketals, xyloallenolide and its precursors from endophytes. 


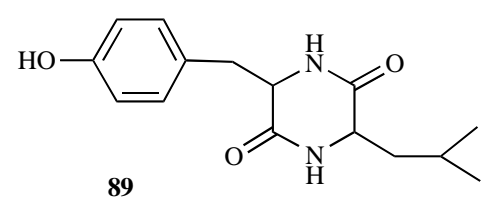<smiles>CC1NC(=O)C(Cc2ccccc2)NC1=O</smiles><smiles>CC1NC(=O)C(C(C)C)NC1=O</smiles><smiles>O=C1NCC(=O)N2CCCC12</smiles><smiles>CC(C)CC1NC(=O)NC1=O</smiles><smiles>CCC(C)[C@H]1NC(=O)[C@H](CC(C)C)NC(=O)[C@H](CC(C)C)NC(=O)[C@H](CC(C)C)NC(=O)[C@H](Cc2ccccc2)NC1=O</smiles><smiles>O=c1cc[nH]c(=O)[nH]1</smiles><smiles>O=C1NC(Cc2ccccc2)C(=O)NC1Cc1ccccc1</smiles><smiles>O=C1CNC(=O)C(Cc2ccccc2)N1</smiles><smiles>CC(C)[C@H]1C(=O)N(C)[C@H](C)C(=O)N1C</smiles>

97

98

Fig. (10). Cyclic peptides from the endophytes.

from the endophytic fungus No. 2534, and cyclo-(Phe-Gly) (97) from the fungus No. 2526. Wang et al. [37] isolated a new cyclic dipeptide, cyclo- $(N$-MeVal- $N$-MeAla) (98), from the fungus No. 2106 from the seeds of A. marina in Hong Kong. The $N$-methyl cyclic dipeptide structure is uncommon in nature.

\section{Sphingolipids}

Sphingolipids are the major lipid components of biological membranes. They serve as structural support and shape determinants of the cell membrane and, via protein binding, act as mediators of biological events such as activation, cell agglutination, intracellular communication, cell death, and cell growth. [38]

Li et al. [39] isolated two new ceramides, [2',3'-dihydroxytetracosanolyamino]-1,3-dihydroxy-octadecane (99) and [2',3'-dihydroxydocosanoylamino]-1,3-dihydroxy-octadecane (100), from the culture extract of an unidentified endophytic fungus ( strain No. 2524) separated from the seed of man- grove A. marina of Hong Kong. These two ceramides didn't exhibit significant cytotoxicity against the human hepatoma cell lines Bel-7402, NCI-4460 and the normal human cell lines L-02 in the preliminary cytotoxic activity investigation.

Zhu et al. [36, 40] found the fungus No. 2526 also can produce the ceramide 99, and can produce other two ceramides, $N$-(2',3'-dihydroxytetracosyl)-1,3-dihydroxy-2-aminooctadecane (101) and $N$-(2',3'-dihydroxyhexacosyl)-1,3dihydroxy-2-amino-octadecane (102), and two glycosphingolipids, 2'-dehydroxycerebroside D (103) and cerebroside D (104). Two ceramides and one glycosphingolipid, were isolated by Zhu et al. [41] from the fungus No. 2534 from the seeds of A. marina. Their structures were tentatively elucidated as $N$-hexacosyl-2-amino-1,3-dihydroxyoctadecane (105), $N$-(2-hydroxyeicosyl)-2-amino-1,3,4-trihydroxyoctadecane (106) and $N$-heneicosanoyl-2-amino-1- $O-\beta$-Dglucopyranosyl-3,4-dihydroxyoctadecane (107), respectively.<smiles>[R]C(CCCC)C([R])C([R])CCCC</smiles>

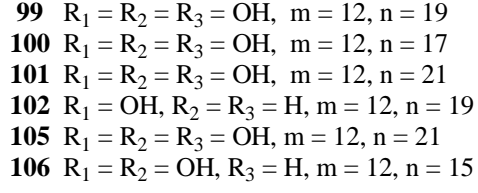

$99 \mathrm{R}_{1}=\mathrm{R}_{2}=\mathrm{R}_{3}=\mathrm{OH}, \mathrm{m}=12, \mathrm{n}=19$ $100 \mathrm{R}_{1}=\mathrm{R}_{2}=\mathrm{R}_{3}=\mathrm{OH}, \mathrm{m}=12, \mathrm{n}=17$ $101 \mathrm{R}_{1}=\mathrm{R}_{2}=\mathrm{R}_{3}=\mathrm{OH}, \mathrm{m}=12, \mathrm{n}=21$ $102 \mathrm{R}_{1}=\mathrm{OH}, \mathrm{R}_{2}=\mathrm{R}_{3}=\mathrm{H}, \mathrm{m}=12, \mathrm{n}=19$ $105 R_{1}=R_{2}=R_{3}=O H, m=12, n=21$ $106 \mathrm{R}_{1}=\mathrm{R}_{2}=\mathrm{OH}, \mathrm{R}_{3}=\mathrm{H}, \mathrm{m}=12, \mathrm{n}=15$

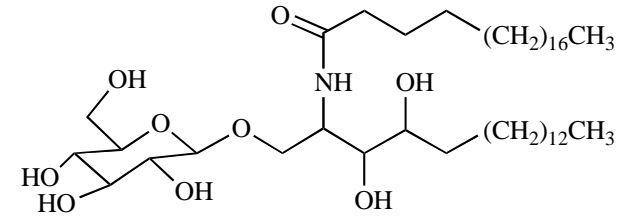

107<smiles>CCCCCCCCCCCCCCC/C=C/C(=O)NC(COC1OC(CO)C(O)C(O)C1O)C(O)/C=C/CC/C=C(\C)CCCCCCCCC</smiles><smiles>CCCCCCCCCCCCCCCCC(O)C(N)=O</smiles><smiles>COC(O)C(O)C(O)C(O)CO</smiles>
$\mathrm{NH}$<smiles>OC1CCCCC1</smiles>

Fig. (11). Sphingolipids from the endophytes. 
<smiles>COc1cc2c(c3oc4cccc(O)c4c(=O)c13)[C@H]1C=CO[C@@H]2O1</smiles><smiles>COc1cc2c(c3oc4cccc(O)c4c(=O)c13)[C@H]1CCO[C@H]1O2</smiles><smiles>COc1cc(O)c(C(CO)C(O)CO)c2oc3cccc(O)c3c(=O)c12</smiles><smiles>CC12CCCC(O1)c1c(cc3c(c1O)C(=O)c1cc(O)cc(O)c1C3=O)O2</smiles><smiles>CC12CCC(O)C(O1)c1c(cc3c(c1O)C(=O)c1c(O)cc(O)cc1C3=O)O2</smiles>

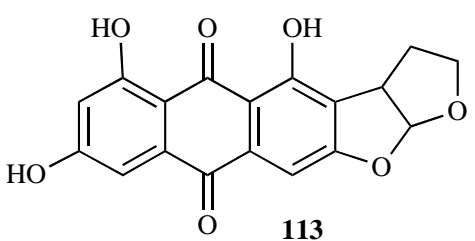<smiles>COc1cc(O)c2c(c1)C(=O)c1cc(C)cc(O)c1C2=O</smiles>

Fig. (12). Xanthones and anthraquinones from the endophytes.

\section{Xanthones and Anthraquinones}

The fungus No. 2526 which was isolated from a petiole of $A$. marina in Hong Kong was shown to also produce xanthones and anthraquinones, two chemical families with biosynthesis correlations. In the previous study [42], the fungus was shown to produce sterigmatocystin (108). Subsequently, fermentation of the fungus in large scale yielded the other two xanthones [43], dihydrosterigmatocystin (109) and secosterigmatocystin (110), and four anthraquinones [44], namely averufin (111), nidurufin (112), versicolorin C (113) and physicion (114). Secosterigmatocystin is a dominance secondary metabolite isolated from the fermentation liquid. The others are isolated from the mycelium. Sterigmatocystin is a dominance metabolite among them. Compound $\mathbf{1 0 9}$ and 110 seems to be derived from the enzymatic hydrogenation and the enzymatic degradation of sterigmatocystin. Anthraquinones 111-113 had been proved to be biosynthetic intermediates for sterigmatocystin.

\section{Steroids, Esters, Lactones and the Others}

Three steroids, namely ergost-6,22-diene-5,8-epidioxy$3 \beta$-ol (4), ergosterol (115) and cerevisterol (116) were produced by the fungi Nos. 2534 [35], 2526 [36], 2508 [31] and 2106 [37]. But only compound 4 were also found to be existed in the leaves of $A$. marina. Four esters, $\alpha$-glycerol monopalmitate (117) [31], (3S,4R)-dihydroxy-(6S)-undecylapyranone (118) [34], no. 2106A (119) [37] and cytosporone B (120) [45] were also found produced by the fungi from $A$. marina. Among them, compunds 118 and 119 are new lactones. Compound $\mathbf{1 2 0}$ was produced by the endophytic fungus Dothiorella sp. HTF3 which was isolated from A. marina at the estuary of Jiulong River, Fujian Province, and showed high antitumor activities and broad antifungi spectra.

In addition, piliformic acid (121) [31], 9-oxo-stearic acid (122) [36] and mannitol (123) [36, 37], was produced by the fungal strains No. 2508, 2526 and 2106, respectively.<smiles>CCCCCCCCCCCC[C@H]1C[C@@H](O)[C@@H](O)C(=O)O[C@H]1CCCCCCCCCCCCCC(=O)OCC(O)CO</smiles><smiles>C[C@]12C[C@H]3C(=O)O[C@H](CO1)[C@H]3O2</smiles>

119<smiles>CCCCCCCC(=O)c1c(O)cc(O)cc1CC(=O)OCC</smiles>

120<smiles>CCCCC/C=C(\C(=O)O)C(C)C(=O)O</smiles>

121

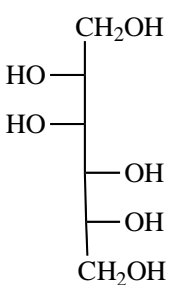

123<smiles>CCCCCCCCCC(=O)CCCCCCCC(=O)O</smiles>

Fig. (13). Steroids, esters, lactones and the others metabolites from endophytes. 


\section{CONCLUSIONS}

To date, sixty-six chemical components were isolated from the different parts of A. marina, and fifty-seven metabolites were obtained from its endophytes. Although lots of compounds produced by the endophytes were not found to be existed in the host A. marina, except compound $\mathbf{4}$, it can still be found that xyloallenoide A (76), aromatic allenic esters $(\mathbf{8 1}$ and $\mathbf{8 2})$ from the endophyte and some glucosides from the host all possess the same structure unit (124). It suggested that they all use the same compound as biosynthetic precursor.

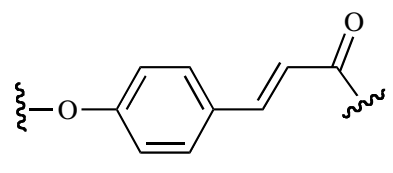

124

Fig. (14). The same structure unit in some compounds from Avicennia marina and its endophytes.

Certainly only six endophytic fungal strains of A. marina have been chemically investigated, they are only a very small part of the endophytes of A. marina and therefore represent great potential for the discovery of new pharmacologically active metabolites. With the deep chemically investigation on the endophytes of A. marina, the relationship between the endophytes and its host A. marina would be revealed completely in the future.

\section{ACKNOWLEDGEMENTS}

This work was supported by the Union Opening Foundation of CAS' Key Laboratory of Marine Bio-resourses Sustainable Utilization (LMB) and Guangdong Provincial Key Laboratories of Applied Marine Biology (LAMB) and Marine Materia Medica (LMM) under contract No. 071019.

\section{REFERENCES}

[1] Pan, J. H.; Jones. E. B. G.; She, Z. G.; Pang, J. Y.; Lin, Y. C. Review of bioactive compounds from fungi in the South China Sea. Botanica Marina, 2008, 51, 179-190.

[2] Fauvel, M. T.; Taoubi, K.; Gleye, J.; Fouraste, I. Phenylpropanoid glycosides from Avicennia marina. Planta Med., 1993, 59, 387387.

[3] Bell, H. K.; Duewell, H. Triterpenoids from the bark of the Avicennia marina. Aust. J. Chem., 1961, 14, 662-664.

[4] Wannigama, G. P.; Volkman, J. K.; Gillan, F. T.; Nichols, P. D.; Johnst, R. B. A comparison of lipid components of the fresh and dead leaves and pneumatophores of the mangrove Avicennia marina. Phytochem., 1981, 20, 659-666.

[5] Hogg, R. W.; Gillan, F. T. Fatty acids, sterols and hydrocarbons in the leaves from eleven species of mangrove. Phytochemistry, 1984, 23, 93-97.

[6] Guo, X. X.; Tao, Z.; Song, W. D. Characteristics of chemical constituents of volatile oil from leaves of mangrove plant Avicennia marina by gas chromatography/mass spectrometry. Tropical Oceanol., 2008, 27(1), 57-59.

[7] Azuma, H. A.; Toyota, M.; Asakawa, Y.; Takaso, T.; Tobe, H. Floral scent chemistry of mangrove plants. J. Plant Res., 2002, 115, 47-53

[8] Huang, L. S.; Zhu, F.; Huang, M. Z. Analysis of the chemical constituents of the essential oil from the fruits of Avicennia marina. Fine Chem., 2009, in press.

[9] Jia, R.; Guo, Y. W.; Hou, H. X. Studies on the chemical constituents from leaves of Avicennia marina. Chin. J. Nat. Med., 2004, 2, 16-19.
[10] Feng, Y.; Li, X. M.; Wang, B. G. Chemical constituents in aerial parts of mangrove plant Avicennia marina. Chin. Trad. Herb. Drugs, 2007, 38(9), 1301-1303.

[11] Han, L.; Huang, X. S.; Dahse, H. M.; Moellmann, U.; Grabley, S.; Lin, W. H.; Sattler, I. New abietane diterpenoids from the mangrove Avicennia marina. Planta Med., 2008, 74, 432-437.

[12] Sutton, D.; Gillan, F. T.; Susic, M. Naphthofuranone phytoalexins from the grey mangrove, Avicennia marina. Phytochemistry, 1985, 24, 2877-2879.

[13] Han, L.; Huang, X. S.; Dahse, H. M.; Moellmann, U.; Fu, H. Z.; Grabley, S.; Sattler, I.; Lin, W. H. Unusual naphthoquinone derivatives from the twigs of Avicennia marina. J. Nat. Prod., 2007, 70, 923-927.

[14] Sharaf, M.; El-Ansari, M. A.; Saleh, N. A. M. New flavonoids from Avicennia marina. Fitoterapia, 2000, 71, 274-277.

[15] Feng, Y.; Li, X. M.; Duan, X. J.; Wang, B. G. Iridoid glucosides and flavones from the aerial parts of Avicennia marina. Chem. Biodivers., 2006, 3, 799-806.

[16] König, G.; Rimpler, H. Iridoid glucosides in Avicennia marina. Phytochemistry, 1985, 24, 1245-1248.

[17] Shaker, K. H.; Elgamal, M. H. A.; Seifert, K. Iridoids from Avicennia Marina. Zeitschrift Fuer Naturforschung C J. Biosci., 2001, 56, 965-968.

[18] Feng, Y.; Li, X. M.; Duan, X. J.; Wang, B. G. A new acylated iridoid glucoside from Avicennia marina. Chin. Chem. Lett., 2006, 17, 1201-1204.

[19] Sun, Y.; Ouyang, J.; Deng, Z. W.; Li, Q. S.; Lin, W. H. Structure elucidation of five new iridoid glucosides from the leaves of Avicennia marina. Magn. Reson. Chem., 2008, 46, 638-642.

[20] Zheng, Z. H.; Miao, L.; Huang, Y. J.; Xu, Q. Y.; Su, W. J. Antitumor activity of mangrove endophytic fungi. J. Xiamen Univ. Nat. Sci., 2003, 42(4), 513-516.

[21] Deng, Z. J.; Cao, L. X.; Tan, H. M.; Vrijmoed, L. L. P.; Zhou, S. N. Study on the antibacterial and antifungal activities of mangrove fungal endophytes. J. Guangdong Coll. Pharm., 2007, 23, 563-567, 571.

[22] Tariq, M.; Dawar, S.; Mehdi, F. S. Isolation of fungi from Avicennia marina. Pak. J. Bot., 2006, 38, 805-810.

[23] Chen, Z. M.; He, J. J.; He, H.; Zhang, X. F.; Song, W. D. Isolation and screening of endophytic antifungal bacteria from mangrove. Microbiology, 2006, 33(3), 18-23.

[24] Lin, Y. C.; Wu, X. Y.; Feng, S.; Jiang, G. C.; Luo, J. H.; Zhou, S. N.; Vrijmoed, L. L. P.; Krohn, K.; Steingrover, K.; Zsila, F. Five unique compounds: xyloketals from mangrove fungus Xylaria sp. from the south china sea coast. J. Org. Chem., 2001, 66, 62526256.

[25] Wu, X. Y.; Liu, X. H.; Lin, Y. C.; Luo, J. H.; She, Z. G.; Li, H. J.; Chan, W.; Antus, S.; Kurtan, T.; Elsasser, B.; Krohn, K. Xyloketal F: a strong L-calcium channel blocker from the mangrove fungus Xylaria sp. (\#2508) from the South China Sea coast. Eur. J. Org. Chem., 2005, (19), 4061-4064.

[26] Wu, X. Y.; Liu, X. H.; Jiang, G. C.; Lin, Y. C.; Chan, W.; Vrijmoed, L. L. P. Xyloketal G, a novel metabolite from the mangrove fungus 2508. Chem. Nat. Comp., 2005, 41, 27-29.

[27] Liu, X.; Xu, F.; Zhang, Y.; Liu, L.; Huang, H.; Cai, X.; Lin, Y.; Chan, W. Xyloketal $\mathrm{H}$ from the mangrove endophytic fungus Xylaria sp. 2508. Russian Chem. Bull., 2006, 55, 1091-1092.

[28] Yin, W. Q.; Lin, Y. C.; She, Z. G.; Vrijmoed, L. L. P.; Jones, E. B. G. A new compound: Xyloketal $\mathrm{H}$ from mangrove fungus Xylaria sp. from the South China Sea coast. Chem. Nat. Comp., 2008, 44, 3-5.

[29] Lin, Y.; Wu, X.; Feng, S.; Jiang, G.; Zhou, S.; Vrijmoed, L. L. P.; Jones, E. B. G. A novel $N$-cinnamoylcyclopeptide containing an allenic ether from the fungus Xylaria sp. (strain \#2508) from the South China Sea. Tetrahedron Lett., 2001, 42, 449-451.

[30] Xu, F.; Zhang, Y.; Wang, J. J.; Pang, J. Y.; Huang, C. H.; Wu, X. Y.; She, Z. G.; Vrijmoed, L. L. P.; Jones, E. B. G.; Lin, Y. C. Benzofuran derivatives from the mangrove endophytic fungus Xylaria sp. (\#2508). J. Nat. Prod., 2008, 71, 1251-1253.

[31] Wu, X. Y.; Li, M. L.; Hu, G. P.; Lin, Y. C.; Vrijmoed, L. L. P. The Metabolites of the endophyte fungus No.2508 in the mangrove tree from the South China Sea coast. Acta Sci. Nat. Univ. Sunyatseni, 2002, 41(3), 34-36.

[32] Liu, X. H.; Xu, F.; Zhang, Y.; Liu, L. H.; Huang, H. R.; She, Z. G.; Lin, Y. C.; Chan W. Crystal structure of 3S-hydroxy-7 melleine. Chin. J. Chem. Phys., 2006, 19, 423-427. 
[33] Li, H. J.; Lin, Y. C.; Liu, X. H.; Zhou, S. N.; Vrijmoed, L. L. P. The Peptides from mangrove endophytic fungus no. 2524 (I). Acta Sci. Nat. Univ. Sunyatseni, 2002, 41(1), 110-112.

[34] Li, H. J.; Lin, Y. C.; Yao, J. H.; Vrijmoed, L. L. P.; Jones, E. B. G. Two new metabolites from the mangrove endophytic fungus no. 2524. J. Asia. Nat. Prod. Res., 2004, 6, 185-191.

[35] Zhu, F.; Lin, Y. C.; Zhou, S. N.; Vrijmoed, L. L. P. Metabolites of mangrove endophytic fungus no.2534 from the South China Sea. Acta Sci. Nat. Univ. Sunyatseni, 2003, 42(1), 52-54.

[36] Zhu, F.; Chen, G. Y.; Lin, Y. C.; Yu, Z. J. Metabolites produced by mangrove endophytic fungi (no.2526 and No.1850) from the South China Sea. J. Liaoning Normal Univ. Nat. Sci. Ed., 2005, 28, 313316.

[37] Wang, S. Y.; Xu, Z. L.; She, Z. G.; Wang, H.; Li, C. R.; Lin, Y. C. Two new metabolites from the mangrove endophytic fungus no. 2106. J. Asia. Nat. Prod. Res., 2008, 10, 622-626.

[38] Zhu, F.; Wu, X. Y.; Lin, Y. C. Advances in the synthesis of glycosphingolipids. Chin. J. Org. Chem., 2002, 22, 817-826.

[39] Li, H. J.; yao, J. H.; Chen, Y. G.; Lin, Y. C.; Vrijmoed, L. L. P. The novel ceramides from a mangrove endophytic fungus no. 2524. Acta Sci. Nat. Univ. Sunyatseni, 2003, 42(6), 132-133.
[40] Zhu, F.; Lin, Y. C.; Zhou, S. N.; Vrijmoed, L. L. P. Sphingosine derivatives isolated from mangrove fungi $2526 \#$ and $1850 \#$ from the South Sea in China. Chem. Indust. Forest Prod., 2004, 24(4), 11-14.

[41] Zhu, F.; Peng, Y. M.; Chen, G. Y.; Lin, Y. C. Sphingolipid metabolites of mangrove endophytic fungus no. 2534 from the South China Sea. J. Foshan Univ. Nat. Sci. Ed., 2007, 25(1), 55-57.

[42] Zhu, F.; Lin, Y. C.; Zhou, S. N.; Vrijmoed, L. L. P. Sterigmatocystin isolated from mangrove endophytic fungus no. 2526. Chin. J. Appl. Chem., 2003, 20, 272-274.

[43] Zhu, F.; Lin, Y. C.; Zhou, S. N.; Vrijmoed, L. L. P. Xanthone derivatives isolated from two mangrove endophytic fungi \#2526 and \#1850 from the South China Sea. Nat. Prod. R. D., 2004, 16, 406409.

[44] Zhu, F.; Lin, Y. C.; Zhou, S. N. Anthraquinone derivatives isolated from marine fungus \#2526 from the South China Sea. Chin. J. Org. Chem., 2004, 24, 1114-1117.

[45] Xu, Q. Y.; Huang, Y. J.; Zheng, Z. H.; Song, S. Y.; Zhang, Y. M.; $\mathrm{Su}, \mathrm{W}$. J. Purification, elucidation and activities study of cytosporone B. J. Xiamen Univ. Nat. Sci., 2005, 44, 425-428.

(c) Zhu et al.; Licensee Bentham Open.

This is an open access article licensed under the terms of the Creative Commons Attribution Non-Commercial License (http://creativecommons.org/licenses/by-nc/3.0/) which permits unrestricted, non-commercial use, distribution and reproduction in any medium, provided the work is properly cited. 